\title{
INTERPRETIVISM AND THE ANALYSIS OF TRADITIONS AND PRACTICES*
}

\author{
Contact addresses: \\ Mark Bevir \\ Department of Political Science \\ University of California \\ Berkeley \\ CA 94720-1950 \\ USA \\ E-mail: mbevir@berkeley.edu \\ and \\ R. A. W. Rhodes \\ Faculty of Social and Human Sciences \\ University of Southampton \\ Murray Building \\ Southampton \\ SO17 1BJ \\ United Kingdom \\ E-mail: r. a.w.rhodes@ soton.ac.uk
}

\section{$\underline{\text { Biographies }}$}

Mark Bevir is a Professor in the Department of Political Science at the University of California, Berkeley.

R. A. W. Rhodes is Professor of Government, University of Southampton, UK; and Adjunct Professor of Governance and Public Policy, Griffith University, Australia.

\footnotetext{
* To be published in Critical Policy Studies 6 (2) 2012: 201-208. A reply to Wagenaar, H. (2012). 'Dwellers on the threshold of practice: the interpretivism of Bevir and Rhodes', Critical Policy Studies, 6, (1): 85-99
} 
We must thank Hendrik Wagenaar not only for his for his generous comments on our work but also for taking the time and trouble to engage with it in such a helpful way. We seek to respond in the same spirit. Although he makes a couple of small theoretical criticisms, his main concern is that there is little empirical work. He argues for a 'performative' account of governance. We comment briefly on the philosophical analysis of practices and traditions, before drawing attention to a broad set of empirical studies and highlighting our core books. Finally, we reflect on the difficulties of documenting traditions, and we compare Wagenaar's emphasis on performance with our account of storytelling.

\section{Practices and traditions}

Wagenaar begins by probing our interpretive theory. He suggests we do not integrate belief and practice enough. Our theoretical writings clearly belie his suggestion. We constantly stress that actions and practices are intrinsically meaningful; they embody the beliefs of the actors and cannot properly be discussed without reference to these beliefs. Also, we constantly emphasize that beliefs are not entities of which people have direct observations but rather entities people postulate to explain actions. In our view, beliefs and practices are indissolubly linked to each other.

Wagenaar's other theoretical suggestion is that our view of tradition is static. Once again our theoretical writings belie his suggestion. In all our theoretical accounts of tradition, we emphasize that traditions are not static classificatory schemes into which to slot examples. We insist traditions are dynamic sets of beliefs people inherit and then adapt for reasons of their own. Most of our work revolves around a pair of concepts - tradition and dilemma - and the concept of dilemma serves explicitly to explain why and how people constantly transform tradition. 
It would be tedious to provide quotations from our earlier work with which to remind readers how we analyse beliefs, actions, practices, and traditions. Besides, we suspect Wagenaar is not criticizing our theory. He does not refer, for example, to our main philosophical work (Bevir 1999). Wagenaar's complaint is not that we do not think of beliefs as linked to practices or of traditions as dynamic. Rather, it is that our empirical work does not do a good enough job of presenting beliefs and traditions as situated in dynamic practices. Wagenaar is, in other words, concerned about the extent to which our empirical work properly instantiates our philosophy.

\section{Empirical work}

Wagenaar refers to a 'the relative paucity of their own empirical work', suggesting 'only a few political scientists ... have applied the conceptual apparatus of British interpretivism to the problematics of governance', and 'as far as I know, no books have so far been published that contain exemplars of British interpretivism in practice'. In his lengthy first footnote, he concedes we do provide empirical examples but considers them 'rather disappointing'. We too were disappointed - by these remarks. We try hard to ensure we ground our theory in historical and ethnographic fieldwork. We regret Wagenaar does not find the fieldwork more compelling or at least a better illustration of our theory. We also regret he has not taken more notice of what we regard as a growing body of empirical work. It includes not only our coauthored books, but also the books we have written singly or with other collaborators, edited volumes, and the work of several colleagues who have taken at least some inspiration from our version of interpretive political science.

We trust readers will look at our empirical work and we hope they will find it more persuasive than does Wagenaar. Here we concentrate on showing readers the range of 
empirical work relevant to any assessment of the strength of our interpretive political science. We also highlight examples of our own work - the core project if you like - which directly address in some detail Wagenaar's concerns.

A question arises, however, about how to define the interpretive approach. We adopted a dual strategy to answer this question. On the one hand, we favour a broad definition of the interpretive approach, encompassing not just our philosophical theories but also governmentality, post-Marxism, interpretive policy analysis, and some forms of social constructivism. Given this definition, the empirical work exemplifying the interpretive approach is vast and complex, containing many competing visions of present-day social and political life. On the other hand, however, we freely admit to working often with a narrower definition of the interpretive approach that ties it directly to our philosophical ideas. We argue for this definition of the interpretive approach, which we see as rooted in historicism and humanism, in contrast to other competing strands within the broader definition. Wagenaar's complaint is, we take it, that there are few empirical studies exemplifying our particular strand of the interpretive approach.

Our interpretive approach focuses, firstly, on recovering the beliefs of policy actors as these appear in their meaningful actions, and secondly, on explaining these beliefs by locating them against the background of traditions and dilemmas. In this way, we decentre governance, highlighting the diversity and contingency of meaningful activity that constitutes patterns of rule, administration, and service delivery. Our appeal to traditions and dilemmas serves a critical purpose. It reveals the contestability and the limits of the narratives, rationalities, and expertise that inform public policy, especially the spread of markets and networks. Far from this decentred view of governance having received little empirical attention, one of our critics has suggested it 'may be becoming the new orthodoxy' (Marsh 2008b: 738). 
The interpretive approach is becoming widespread as more and more colleagues draw on, if not fully endorse, some of our arguments. To demonstrate the point, there is no more economical way of providing the information than a simple listing. In so doing, it is probably impossible to avoid giving the impression of self-advertisement but that is not our aim. Rather, we only seek to provide up-to-date and accurate information. We include articles drawing on our work if and only if they cite us and use one or more of our key concepts web of belief, practices, narrative, tradition, and dilemma. Articles that critically discuss our work, but do not draw on it and one or more of these concepts, we relegate to critical discussions. Obviously, the following categories overlap, and our attempt to slot items neatly under one or other category is at best foolhardy and probably actively misleading.

\section{Public policy}

Bevir, Rhodes, and Weller 2003; Bevir and Gains 2011; Bevir and Trentmann, 2003;

Clark and Gains 2007; Grube 2011; Jose 2007; Stoker 2006; Sullivan et. al. 2012;

Wilkinson 2011; Wood, Fleming and Marks 2008.

Policy networks.

Ball 2008; Bevir and Richards 2009; O’Brien, et al. 2009.

Democracy and the state

Bevir 2010; Bevir and Rhodes 2010.

Gender and Race

Monro 2006; Mackay and Rhodes 2012; Stow 2010.

Local and urban politics 
Bache and Catney, 2008; Dinham, and Lowndes 2008; Gains 2009; Gibbs and Krueger 2011; Krueger and Gibbs 2010; Orr 2005 and 2009; Orr and Vince 2009; Sullivan 2007.

\section{British politics}

Bevir 2005; Bevir and Rhodes 2003; Booth 2010; Dudley 2003; Edwards 2011;

Finlayson 2008; Finlayson and Martin 2008; Kenny 2010; Meredith and Catney 2007;

Morrell 2006; Rhodes 2011; Richards and Mathers, 2010; Richards and Smith, 2004;

Stark 2011.

\section{Comparative politics}

Bevir, Rhodes and Weller 2003; Craig 2006; Irazabal 2005; Rhodes, Wanna, and Weller 2009.

\section{International relations}

Bratburg 2011; Daddow 2011; Hall 2012; Lindsey and Grattan 2011; Yi-Chong and Weller 2007.

\section{Methods}

Bevir and Rhodes 2006; Fleming 2008; Gains 2011; Rhodes, t'Hart, Noordegraaf 2007.

Our listing comprises the empirical work that is Wagenaar's main concern. Our critics often touch on theory, methods and empirical work together. There is a growing literature engaging with the philosophy; the most extensive discussions of Bevir (1999) are Burrow (2002) and Lamb (2011). There is also a growing literature engaging with our use of this philosophy to 
develop interpretive political science; discussions of Bevir and Rhodes (2003, 2006, and 2010) include Finlayson (2004), Glynos and Howarth (2008), Hay (2011), Lawson (2008), Marinetto (2003), Marsh (2008a and 2008b), McAnulla (2005 and 2006), Rhodes (2007), Smith (2008), and Wagenaar (2011).

At this point, we could go on to summarise in more detail our empirical work but that would take a deal of space and no doubt tax the patience of editors and readers alike. However, some signposts to the core of our work will help if only because previously we have not sought to draw attention to our work in the round. Our philosophy is based on Bevir (1999). In our work, we engage in both detailed ethnographic studies to recover the beliefs in action and historical genealogies of how these beliefs in action arose against the background of particular traditions and dilemmas (Bevir and Rhodes 2003, 2006 and 2010). The most recent ethnographic book is Rhodes 2011 but see also Rhodes, 't Hart and Noordegraaf 2007. The most recent genealogy of traditions is Bevir 2010. In future, we hope our critics will engage with these theoretical and empirical studies. For now, we content ourselves with the observation that Wagenaar's claim there is a paucity of empirical material is inaccurate, and the conclusion that our empirical work is 'disappointing' is - or so we hope - premature. Our fieldwork may well fall short of Geertz's 'interpretive brilliance' but we would be disappointed if Wagenaar felt it lacked ‘empirical and analytical sophistication’. However, and possibly most important, we welcome this opportunity to draw attention to the scope of interpretive political science not only in our work but that of many colleagues.

\section{Beyond the threshold}


We said we would seek to respond positively to the various criticisms. Wagenaar touches on two topics where we share his interest and concern; documenting traditions and a performative account of governance

\section{Documenting traditions}

Anyone seeking to ground theory will struggle at times, and we are no exception. We accept that we latched on to the traditions found in conventional accounts of British government. The brutally simple fact is that we have had limited resources with which to do detailed and thorough historical analysis. Also, there is little secondary literature we can draw on to explore such notions as, for example, departmental courts and their associated departmental philosophies. In our account, traditions are flexible vehicles for explaining beliefs, actions, and practices. The problem is that in any society there are many traditions and, still more important, scholars reasonably can demarcate traditions in different ways depending on what they want to explain. If we are to avoid essentialist accounts of tradition, then we have to document afresh whatever set of beliefs or actions happen to be of interest. Traditions are essentially artifacts, always constructed and interpreted by the observer and justified by the claim that they best explain what is of interest to us. So, we agree that our account of the traditions in British government were not sufficiently 'dynamic and fine-grained'. But in mitigation, we plead that such defects stemmed from limited resources, occurred mainly in the early stages of our joint project, and that our more recent genealogies seek to address the problem (see Bevir 2005 and 2010; Rhodes, Wanna and Weller 2009).

\section{A performative account of governance}

We welcome Wagenaar's emphasis on performative accounts. Indeed, we arrived at much the same conclusion but by a different route. In our philosophy, we adopted the concept 'narrative' to describe the historicist form of explanation that we were after in contrast to the 
more formal forms of explanation typically favoured by, for example, the new institutionalism and rational choice theorists (Bevir 1999; Bevir and Rhodes 2003). Narrative plays a dual role in our theories. The term refers, first, to the stories by which the people we studied made sense of their worlds. Second, it refers to the stories by which we made sense of the narratives and actions of the people we studied.

Later, as we began to supplement our historical and textual studies with more ethnographic fieldwork, we found an echo of our views in organization studies. In particular, we found the growing literature on storytelling consistent with our use of narratives and an insightful way of analysing the everyday actions of political actors (see for example: Czarniawska 2004; Gabriel 2000). Thus, we reported how ministers, civil servants, police officers, and citizens use stories to make sense of their world, to gain and pass on information, to inspire involvement, to persuade others to act in certain ways, and as the repository of the organization's institutional memory (Bevir and Rhodes 2006 and 2010; Rhodes 2011).

Thus, Rhodes (2011) reports that most if not all civil servants will accept that the art of storytelling is an integral part of their work. Such phrases as: 'Have we got our story straight?', 'Are we telling a consistent story?', and 'What is our story?' abound. Civil servants and ministers learn and filter current events through the stories they hear and tell one another. Stories explain past practice and events and justify recommendations for the future.

Such storytelling had three characteristics: a language game, performing game and management game. The language game identified and constructed the story-line, answering the questions of what and happened and why. The resulting story had to be reliable, defensible, accurate and consistent with the department's traditions. The performing game told the story to a wider audience, inside and outside the department. Officials tested the facts and rehearsed the story-line in official meetings to see how their colleagues responded. They 
had to adapt the story to suit the minister, and both ministers and officials had to judge how the story would play publicly. They then performed that agreed story on a public stage to the media, parliament and the public. Finally, there was the management game, which both implemented any policy changes and perhaps even more important let them get on with 'business as usual' as quickly as possible.

In short, we suggest that recovering other people's stories is an excellent method for doing fine-grained interpretive research; at the end, there is a meeting of minds.

\section{References}

Bache, I., and P. Catney. 2008. Embryonic associationalism: New Labour and urban governance. Public Administration 86 (2): 411-28.

Ball, S. 2008. New philanthropy, new networks and new governance in education. Political Studies 56 (4): 747-765

Bevir, M. 1999. The logic of the history of ideas. Cambridge: Cambridge University Press.

Bevir, M. 2005. New Labour: a critique. London: Routledge.

Bevir, M. 2010. Democratic governance. Princeton: Princeton University Press.

Bevir, M., and F. Gains, Eds. 2011. Ideas into policy: governance and governmentality. Policy \& Politics, special issue 39 (4).

Bevir, M., and D. Richards, Eds. 2009. Decentring policy networks. Public Administration, special issue, $88(1)$.

Bevir, M. and R. A. W. Rhodes. 2003. Interpreting British governance. London: Routledge. 
Bevir, M. and R. A. W. Rhodes. 2006. Governance stories. London: Routledge.

Bevir, M. and R. A. W. Rhodes. 2010. The state as cultural practice. Oxford: Oxford University Press.

Bevir, M., R. A. W. Rhodes, and P. Weller, Eds. 2003. Traditions of governance: history and diversity. Public Administration, special issue, 81 (1).

Bevir, M., and F. Trentmann, Eds. 2003. Governance, consumers, and citizens: agency and resistance in contemporary politics. Basingstoke: Palgrave Macmillan.

Booth, A. 2010. The traditional standpoint of historians: tradition and the construction of educational identity in late twentieth-century British higher education. Contemporary British History 24 (4): 493-509.

Bratburg, O. 2011. Ideas, tradition, and norm entrepreneurs: retracing guiding principles of foreign policy in Blair and Chirac's speeches on Iraq. Review of International Studies 37 (1): $327-348$.

Burrow, J., Ed. 2002. Mark Bevir and the Logic of the History of Ideas. History of European Ideas, special issue, 28 (1).

Clark, K., and F. Gains, Eds. 2007. Constructing delivery: implementation as an interpretive process. Critical Policy Analysis, special issue, 1 (2).

Craig, D. 2006. Community well-being strategy and the legacies of the new institutionalism and new public management in Third Way New Zealand. In L. Bauld, K. Clarke, and T. Maltby, Eds., Analysis and Debate in Social Policy. Bristol: Policy Press, 193-220.

Czarniawska, B. 2004. Narratives in social science research. London: Sage. 
Daddow, O. 2011. New Labour and the European Union: Blair and Brown's logic of history. Manchester: Manchester University Press.

Dinham, A., and V. Lowndes. 2008. Religion, resources, and representation: three narratives of faith engagement in British urban governance. Urban Affairs Review 43 (6): 817-45.

Dudley, G. 2003. Ideas, bargaining and flexible policy communities: policy change and the case of the Oxford transport strategy. Public Administration 81 (3): 433-458.

Edwards, A. 2011. Interpreting New Labour's political discourse on the peace process. In K. Hayward and C. O’Donnell, Eds., Political discourse and conflict resolution: debating peace in Northern Ireland. Abingdon: Routledge, 46-61.

Finlayson, A. 2008. Characterizing New Labour: The case of the Child Trust Fund. Public Administration 86 (1): 95-110.

Finlayson, A., and J. Martin. 2008. "It ain't what you say ...": British political studies and the analysis of speech and rhetoric. British Politics 3 (4): 445-64.

Finlayson, A., Ed. 2004. The interpretive approach in political science: a symposium. British Journal of Politics and International relations 6 (1): 1-36.

Fleming, J. 2008. Managing the diary: what does a police commissioner do? Public Administration 86 (3): 679-698.

Gabriel, Y. 2000. Storytelling in organizations: facts, fictions and fantasies. Oxford: Oxford University Press.

Gaines, F. 2009. Narratives and dilemmas of local bureaucratic elites: Whitehall at the coal face. Public administration 87 (1): 50-64. 
Gains, F. 2011. Elite ethnographies: potential, pitfalls and prospects for getting 'up close and personal. Public Administration 89 (1): 156-166.

Gibbs, D., and R. Krueger. 2011. Fractures in meta-narratives of development: an interpretive institutionalist account of land use development in the Boston city-region. International Journal of Urban and Regional Research (DOI: 10.1111/j.1468-2427.2011.01061.x).

Grube, D. 2011. What the secretary said next: 'public rhetorical leadership' in the Australian public service. Australian Journal of Public Administration 70 (2): 115-130.

Glynos, J., and D. Howarth. 2008. Structure, agency and power in political analysis: beyond contextualized self-interpretations. Political Studies Review 6 (2), 155-169.

Hall, I. 2012. The dilemmas of decline: British intellectuals and world politics, 1945-1975. Berkeley: University of California Press.

Hay, C. 2011. 'Interpreting interpretivism, interpreting interpretations: 'the new hermeneutics of public administration'. Public Administration 89 (1): 167-82.

Irazabal, C. 2005. City making and urban governance in the Americas: Curitiba and Portland. Aldershot: Ashgate.

Jose, J. 2007. Reframing the 'governance' story. Australian Journal of Political Science 42 (3): 455-70.

Kenny, C. 2010. At ideological loggerheads: identifying and clarifying the discursive differences between Blair and Brown on education. British Politics 5 (3): 367-84.

Krueger, R., and D. Gibbs. 2010. Competitive global city regions and 'sustainable development. Environment and Planning A 42 (4): 821-37. 
Lamb, R. 2011. Post-analytic hermeneutics: themes from Mark Bevir's philosophy of history. Intellectual History Review, special issue, 21 (1).

Lawson, S. 2008. Political studies and the contextual turn: a methodological/normative critique. Political Studies 56 (3): 207-230.

Lindsey, I., and A. Grattan. 2012. An 'international movement'? decentring sport-fordevelopment within Zambian communities. International Journal of Sport Policy and Politics 4 (1): 91-110.

Mackay, F., and R. A. W. Rhodes 2013. Gender, greedy institutions and the departmental court. Public Administration. Doi: 10.1111/padm.12012.

Marinetto, M. 2003. Governing beyond the centre: a critique of the Anglo-Governance school. Political Studies 51 (3): 592-608.

Marsh, D. 2008a. Understanding British government: analysing competing models. British Journal of Politics and International Relations 10 (2): 251-268.

Marsh, D. 2008b. What is at stake? A response to Bevir and Rhodes. British Journal of Politics and International Relations 10 (4): 735-739.

McAnulla, S. 2005. British politics: A critical introduction. London: Continuum.

McAnulla, S. 2006. Challenging the new interpretivist approach: towards a critical realist alternative. British Politics 1 (1): 113-38.

Meredith, S., and P. Catney. 2007. New Labour and associative democracy: old debates in new times? British Politics 2 (3): 347-371. 
Monro, S. 2006. New institutionalism and sexuality at work in local government. Gender, Work and Organization 14 (1): 1-19.

Morrell, K. 2006. Policy as narrative: New Labour's reform of the National Health Service. Public Administration 84 (2): 367-85.

O’Brien, M., A. Atkinson, D. Burton, A. Campbell, A. Qualter, and T. Varga-Atkins. 2009. Social inclusion and learning networks: 'a wider notion of learning' or taking things in a different direction. Research Papers in Education 24 (1): 57-75.

Orr, K. 2005. Interpreting narratives of local government change under the Conservatives and New Labour. British Journal of Politics and International Relations 7 (3): 371-85.

Orr, K. 2009. Local government and structural crisis: an interpretive approach. Policy and Politics 37 (1): 39-55.

Orr, K., and R. Vince. 2009. Traditions of local government. Public Administration 87 (3): 655-677.

Rhodes, R. A. W. 2007. 'Understanding Governance: ten years on'. Organization Studies, 28 (8): $1243-1264$

Rhodes, R. A. W. 2011. Everyday life in British government. Oxford: Oxford University Press.

Rhodes, R. A. W. 2012. Theory, method and British political 'life history'. Political Studies Review 10 (1): 161-176.

Rhodes, R. A. W., J. Wanna, and P. Weller. 2009. Comparing Westminster. Oxford: Oxford University Press. 
Rhodes, R. A. W., P. t'Hart, and M. Noordegraaf, Eds. 2007. Observing government elites: up close and personal. Basingstoke: Palgrave Macmillan.

Richards, D., and H. Mathers. 2010. Political memoirs and New Labour: interpretations of power and the club rules. British Journal of Politics and International Relations 12 (4): 498522.

Richards, D., and M. Smith. 2004. Interpreting the world of political elites. Public Administration 82 (4): 777-800.

Smith, M. 2008. Re-centring British government: Beliefs, traditions and dilemmas in political science. Political Studies Review 6 (2): 143-154.

Stark, A. 2011. The tradition of ministerial responsibility and its role in the bureaucratic management of crises. Public Administration 89 (3): 1148-1163.

Stoker, G. 2006. Public value management. A new narrative for networked governance? American Review of Public Administration 36 (1): 41-57.

Stow, S. 2010. Agonistic homegoing: Frederick Douglass, Joseph Lowery, and the democratic value of African American public mourning. American Political Science Review 104 (4): 681697.

Sullivan, H. 2007. Interpreting 'community leadership' in English local government. Policy and Politics 35 (1): 141-162.

Sullivan, H., P. Williams, and S. Jeffares. 2012. Leadership for collaboration: situated agency in practice. Public Management Review 14 (1): 41-66.

Wagenaar, H. 2011. Meaning in action: interpretation and dialogue in policy analysis. New York: M. E. Sharpe. 
Wilkinson, K. 2011. Organised chaos: an interpretive approach to evidence based policy making in DEFRA. Political Studies 59 (4): 959-77

Wood, J., J. Fleming, and M. Marks. 2008. Building the capacity of police change agents: the Nexus Policing project. Policing and Society 18 (1): 72-87.

Yi-Chong, X., and P. Weller. 2007. To be, but not to be seen: exploring the impact of international civil servants. Public Administration 86 (1): 35-51. 